\title{
The integrated work between medicine and psychology with infertile couples at a public hospital in Rio de Janeiro/Brazil
}

\author{
Helena Prado Lopes ${ }^{1}$ \\ ${ }^{1}$ Psicóloga, terapeuta de casal e família \\ Membro titular da ATF-RJ (Associação de Terapia de Família do Rio de Janeiro). Membro da AFTA (American \\ Family Therapy Academy). \\ Colaboradora no Instituto de Ginecologia da UFRJ, setor de Reprodução Humana (Hospital Moncorvo Filho)
}

\begin{abstract}
This study examines the coping process of infertile couple during diagnostic investigation and treatment, which is held in a public hospital in the Assisted Reproduction Treatment department. This analysis discusses the results of a qualitative research whose goal is to emphasize the importance of integrating the medical and psychological care to infertile couples. To collect the data, it uses a semistructured psychological interview. This feature promotes a differentiated listening emotional aspects experienced by patients, allowing couples to greater reflection about their difficulties before the process of investigation and treatment of infertility. From the data, it appears that in addition to medical treatment, patients require in a psychological intervention centered emotional effects experienced by them throughout the process. Given the complexity of the process of Assisted Reproduction, it is essential to consider both the medical factors, essential for achieving the concept of biological child, as psychological factors, at the individual, marital and social. We conclude that the psychological dimension integrated medical help these patients to maximize their resources and seek more adaptive ways to minimize the possible dilemmas and anxiety experienced.
\end{abstract}

Keywords: marital infertility; integration; medicine, psychology; public hospital

\section{INTRODUCTION}

Studies, according to the World Health Organization (WHO) done in 2002 , indicate that the number of infertile couples has increased considerably. It is estimated that from $15 \%$ to $20 \%$ of people of reproductive age are unable to have children by natural conception. Therefore, there is a growing demand for Assisted Reproduction Treatment (ART).

The experience of infertility and its treatment can be profoundly distressing. It is growing problem and across virtually all cultures and societies almost all over the world and affects a great number of couples. In recent years, the number of couples seeking treatment for infertility has dramatically increased due to factors such as postponement of childbearing in women, development of newer and more successful techniques for infertility treatment, and increasing awareness of available services.

Parenthood is one of the major transitions in adult life for both men and women. The stress of the non-fulfillment of a wish for a child has been associated with emotional squeal such as anger, depression, anxiety, marital problems and feelings of worthlessness. Partners may become more anxious to conceive, ironically increasing

sexual dysfunction and social isolation. Marital discord often develops in infertile couples, especially when they are under pressure to make medical decisions.

Studies based on descriptive interviews with infertile couples reveal emotional consequences including feelings of loss of control; a lowered sense of personal competence; hopelessness and a sense of social stigma.

The treatment process and the invasive nature of infertility therapy is a strain on the relationship for the couples. Empi- rical investigations of the impact of infertility have demonstrated that infertile couples tend to experience greater anxiety, depression, and self-esteem than their peers. Women tend to avoid daily reminders, such as, contact with babies and pregnant women because they struggle more than men. They also seek information about infertility, initiate the treatment, and continue the treatment more than their partners. Women who undergo in vitro Fertilization (IVF) contemplate it as one of the worst experiences of their lives.

The diagnosis of infertility causes men to question their masculinity. Male factor infertility is frequently associated with high levels of stigma. This stigma adds to the heightened insecurities in infertile men. He is often primarily relegated to the role of hand-holder, in charge of providing support for his partner during her grieving process. This conforms to society's gender expectations, in which men are not given permission to express deep feelings of loss; on the contrary, they are encouraged to suppress emotions. Men also report feeling specific losses when infertile, such as loss of genetic continuity and passing on the family name, loss of male sexual identity, loss of their ability to control their own lives, and loss of their ability to provide for their partners.

This study's objective is to show the importance of integrating the medical and the psychological teams that work with the couples under ART at a public hospital in Rio de Janeiro. Both teams have to take in consideration the emotional conditions of the couples.

\section{MATERIAL AND METHODS}

We use the concepts and the techniques of the Systemic Relational Method and of the Narrative Therapy. We focus on the emotions that arise from the relationship between the partners and the relationship among the partners and their families.

The Systemic Relational Method investigates the marital dynamics; the family origin of the partners; the social network; the third party, e.g., surrogate mother, egg and sperm donors.

The Narrative Therapy includes to activate the resources of each partner and in particular the dynamics of the infertile couple; to transform the effect that the problem has on people life; to create positive interactions and transforming negative communication or responses into more accepting, non-judgmental and meaningful exchanges; to provide a welcoming, encouraging expression of feelings, anxiety relief due process; to provide necessary psychological support to cope with infertility.

In Narrative Therapy, as well as couple therapy, the psychologist is interested in helping people describe their stories and trajectories, mode of living and possibilities associated with them. At the same time, the psychologist is interested in co-investigating a problem's many influences, including on the personal himself and on their chief relationships. By focusing on problem's effects on people's lives rather than on problems as inside or part of people, distance is crea- 
ted. Narrative Therapy uses the stories people bring about themselves and their lives, to re-shape new lenses, new stories and new experiences.

The psychology department of ART at Moncorvo Filho Hospital is used as a reference for this study: the routine that service consists in psychological interviews with women, or couples who are undergoing treatment. The purpose of this study is to obtain information ranging from the history of the infertile couple life through the meaning of individual, marital and social diagnosis of infertility. It is noteworthy that patients belong, mostly, to the working class, with a small number of the lower middle class.

A questionnaire on the desire for a child was designed by the mental health professional to identify potential expectations and apprehensions in connection with pregnancy, birth and parenthood: "I would be very lonely without a child", or "only if a had a child I would feel that I am a real woman" While ambivalence about parenting appeared: "I am afraid of the demands made by a child", or "I fear that a child might strain my relationship with my partner". And ambivalence about career and self-realization: "there are other things in life I find just as fulfilling as having a child" or "I am afraid that a child might interfere with my career prospects".

Using this questionnaire, patients were asked: how long they have been wanting a child, what treatment they have undergone, which ones they accepted and which ones they rejected, and the participation of their families in fertility treatment. A questionnaire on stress-inducing events in the couples' lives was included and questions related to (previous and present) stressful events in the family of origin to evidence the in-family stress in connection with the desire for a child.

This research is a retrospective study, developing a qualitative analysis of the reports of interviews with women and infertile couples during the year 2012. The total number of people participating in the sample is 200 .

\section{RESULTS AND DISCUSSION}

This paper describes some psychosocial characteristics, e.g., motivation, fears and expectations of patients from the department of human reproduction at a public hospital besides to investigate the emotional consequences of the diagnosis and treatment of infertility to the marital relationship. This sample consists of women and men in the diagnostic phase of investigation of the causes of infertility in couples, the majority $(60 \%)$ belonging to the age group that comprises the ages of twenty-eight years for women and thirdthree years for men.

Men and women report the demand of the social context by the absence of children and both claim to want to, from the son, the deepening of the love relationship between them, they also report the goal of having offspring, continuing their existences. Some women declare the desire to have a child of her partner trying to prevent him from returning to the ex-partner who had already had children.

All people in this study for reasons more or less differentiated, have hopes of seeing solved all problems related to infertility of the couple and consequently being able to have the desired biological child.

The analysis notes that the experience of infertility is experienced by women as an alienation of the social context. They feel like they have broken a socio-cultural rule and tend to label as abnormal. It is also noted that, culturally, a family is still a role assigned to women more than to men. From the observation of the sample of men who participate of the treatment emerge that, for them, it is very difficult to demonstrate their infertility, consequently they feel depreciated and this feeling make them confuse and less potent, feeling as a "sexual failure". It is common for a woman to feel "less of a woman" and for a man "less of a man", when faced with infertility.

When a couple is facing infertility, they should face it as a couple. The emotional suffering on the man and the woman are different, but deep just the same. If couples can keep the lines of communication open and support one another - both sexes can handle it more positively. Often, what the female lacks in her thinking, the man can make up for and vice versa. Still, the time has come to think of infertility as more than just a woman's or a man's issue and see it as one that affects a couple.

\section{THE SAMPLE}

The average of the time couples reported being married was eight years. In relation to the experience of maternity/ paternity, $80 \%$ reported not having children. The others say they have children from previous relationships. Concerning the period of time that they are trying to become pregnant, most report from four years to eight years.

Among the couples interviewed, most do not want to reveal to their relatives and friends about their infertility condition which occurs due to the shame of feeling infertile.

In the same study, it appears that many women $(60 \%)$ say they have resorted to information through television documentaries on both the emotional aspects of infertility, and the ways of dealing with the problem. Watching these documentaries result in a decrease in anxiety because they discover they are not the only ones having difficulty coping with infertility. Moreover, women often notice that these documentaries help their family and their friends better understand the impact that infertility can have on their lives.

When asked about motivation to have a child, $100 \%$ of women say that a child is missing in their lives, with stories such as: "There comes a time that something is missing". "I'm worried about my age. Then I can not have children". "My husband has already had a son with another woman. I want to give a son to him". Men say: "my brothers have already had children. I also want one". "The friends charge me, say they are very virile and potent and I wonder when I will be".

As for adoption, both women and men often say they would adopt a child if they could not have biological children. In this particular case, adoption is seen as a positive thing and can happen.

There is also a minority of women and men (30\%) that perceive adoption as something negative, a result of their failure as a man and a woman. "If I cannot have my own son, I do not want another one".

The sample allows us to observe the similarities and differences between expectations and experiences of women who are starting the treatment and those who had experienced any failure regarding medical procedures. In this sample, it appears that often they start treatment with optimism, denying any possibility of failing to achieve pregnancy. However, as attempts are not successful, there is an increase in anxiety and fear of the possibility of not having the desired child.

The results in general indicates: women that do not yet have children, when their partners already have them, from previous relationships, feel threatened, including abandonment, fantasizing that their partners will return to women they had a son with. The results in general suggest that women may be more adversely affected by infertility than men.

In the study described here, it appears that most couples $(80 \%)$ refer to their marital relationship as satisfactory, indicating thus the lack of reported significant marital difficulties. These studies suggest that the impact of infertility on marital relationships depends on the sociocultural context. In some settings where women's roles are more closely tied to having children, where conceiving children for one's family is considered an important obligation and where marriage is defined in terms of having and raising children, infertility is likely to have a greater negative impact on couple relationships.

Our analysis of infertile couples' descriptions of the effects of infertility on their sexuality certifies that there is an impact on self-image; that the sex is adversely affect due to having to schedule intercourse; that the privacy is invaded; that the intercourse itself is a reminder of the couples' infertility and also that the intercourse becomes a means to an end.

\section{CONCLUSION}

Advances in Assisted Reproductive Techniques for infertile 
people bring new perspectives and above all hope of being able to fulfill the desire to have children.

However, the lack of resources of the Unified Health System (SUS) in Rio de Janeiro at the Moncorvo Filho Hospital prevents the continuity of the treatment, allowing only as a resource the low-complexity of the Assisted Reproduction Techniques generating, because of this, anxiety and conflict. Given the scarce resources to meet the expectations and needs of infertile people, we can point that the State needs to review how the treatment of ART is being offered through the public health care system. It does not correspond and does not meet the demand and the desire of infertile people of the lower classes who are waiting for such treatment.

The goal of the psychological work is to offer the possibility to the couple to share some personal issues and/or discuss marital controversy relative to the whole process of the experience of the infertility.

The mental health professional specialized in ART should work together with the physicians. It is necessary that the psychological practice is associated with the technological aspects of ART.

Psychologists, according to their theoretical approach and the demand of the patients undergoing ART, can use individual, group or couple therapy.

\section{GIVEN THE STRESSFUL NATURE OF ART}

- The anxiety generated by them;

- The individual and marital frustration regarding plans and future projects;

- The possible triggering of depression symptoms. Infertile couples have in the therapeutic setting something beyond the biological dimension. The mental health professional is able to assess the person's or the couple's strengths and vulnerabilities, and explore coping styles and belief systems. He/she can identify expectations about treatment and discuss moral and ethical issues that may arise during the treatment process. Couples can learn ways to understand each other better and communicate more effectively. The goal of infertility psychologist is to increase resiliency, which will support patients and couples throughout their infertility journey, regardless of where it takes them.

This research had the purpose to suggest the possibility of developing a team work to psychology. The result of our research demonstrates the importance of the psychological work throughout the medical process of assisted reproduction. The psychologist plays a supporting role, to the patient and the medical staff, from diagnosis to the end, whatever the outcome of treatment achieved.

\section{REFERENCES}

Burns LH; Covington SN. Infertility Counseling: A Comprehensive Handbook for Clinicians. Cambridge University Press, New York. 2006.

Chilik C. Por qué no podemos tener un hijo? Atlántida, Buenos Aires. 2006.

Diamond KR; Meyers M; Scharf CN., Weinshel M. Couple Therapy for Infertility. The Guilford Press, New York. 1999.

Lopes HP. Ser pai \& Mãe no século XXI. Desejo aliado à tecnologia. Bandeirante, Rio de Janeiro. 2010.

Olmedo SB. También es Asunto de Hombres: El por qué de la infertilidad masculina. Atlántida, Buenos Aires. 2003.

Silva MCP; Solis-Ponton L. Ser Pai, Ser Mãe Parentalidade: um desafio para o terceiro milênio. Casa do Psicólogo, São Paulo. 2004.

Sommer ES. "Nuevas formas de procréación". In: Scavone, Lucila (Org.). Género y salud reproductiva en América latina. Livro Universitário Regional, p. 307-332. Costa Rica.1999.

Souza MCB; Moura MD; Grynszpan D (Orgs). Vivências em Tempo de Reprodução Assistida. O dito e o não-dito. Revinter, Rio de Janeiro. 2006.

Straube KM. Da Família Pensada à família Vivida: Estigma, Infertilidade e as Tecnologias Conceptivas. Dissertação de Mestrado, Universidade Federal do Paraná. Departamento de Ciências Sociais. Curitiba. 2007.

Tubert S. Mujeres sin sombra. Maternidad y tecnología. Siglo Veintiuno, Madrid. 1991.

Urdapiletta L. Aspectos Psicológicos de la infertilidad . In: Chillik C. Porqué no podemos tener un hijo? Atlántida, Buenos Aires. 2000.

Urdapiletta, L. Construcción de familias con la asistencia de gametas donadas. Consideraciones psicológicas, anonimato y derecho a la identidad. Derecho de familia. Revista Interdisciplinaria de Doctrina y Jurisprudencia, no 41. "Las nuevas tecnologías y el derecho de familia". p. 111-128. Abeledo Perrot, Buenos Aires. 2008. 